\title{
Determinan Profitabilitas PT. Unilever Indonesia Tbk
}

\author{
Erlindawati ${ }^{1}$, Early Ridho Kismawadi ${ }^{2}$ \\ IAIN Langsa ${ }^{1}$, IAIN Langsa ${ }^{2}$ \\ erlindawa185@gmail.com ${ }^{1}$, kismawadi@iainlangsa.ac.id ${ }^{2}$
}

\begin{abstract}
The purpose of this study was to determine the effect of debt to equity ratio, selection, size, and curent ratio on profitability at PT. Unilever Indonesia Tbk, which is listed on the Indonesia Stock Exchange for the period 2013-2018. The population in this study consisted of 30 companies belonging to the Jakarta Islamic Index with a 6year research period. While the sample from this study is PT. Unilever Indonesia Tbk. Data were analyzed using multiple regression methods and using SPSS software. The results showed that partially DER had no significant effect (with a value of $t-2.008$ and a significant value of 0.061) on profitability. Sales do not have a significant effect (with $t$ count -0.070 and significant value 0.945) on profitability. Size does not have a significant effect (with a t-value of -0.696 and a significant value of 0.496 ) on profitability. CR has a significant effect (with $t$ count 2,249 and significant value 0,038) on profitability. Simultaneously shows that the debt to equity ratio, sales, size and curent ratio have a simultaneous effect on the dependent variable (profitability) where F count is 5.347 and F table is 2.96 .
\end{abstract}

Keywords: Profitability, Debt to Equity Ratio (DER), Sales, Size, Curent Ratio (CR)

\begin{abstract}
Abstrak
Tujuan dari penelitian ini adalah untuk mengetahui pengaruh debt to equity ratio, seles, size, dan curent ratio terhadap profitabilitas pada PT. Unilever Indonesia Tbk yang terdaftar di Bursa Efek Indonesia periode 2013-2018. Populasi dalam penelitian ini terdiri dari 30 perusahaan yang tergolong dalam Jakarta Islamic Index dengan periode penelitian 6 tahun. Sedangkan sampel dari penelitian ini adalah PT. Unilever Indonesia Tbk. Data dianalisis dengan menggunakan metode regresi berganda dan menggunakan software SPSS. Hasil penelitian menunjukkan bahwa secara parsial DER tidak berpengaruh signifikan (dengan nilai t hitung -2,008 dan nilai signifikan 0,061) terhadap profitabilitas. Sales tidak berpengaruh signifikan (dengan nilai t hitung -0,070 dan nilai signifikan 0,945) terhadap profitabilitas. Size tidak berpengaruh signifikan (dengan nilai t hitung -0,696 dan nilai signifikan 0,496) terhadap profitabilitas. CR berpengaruh signifikan (dengan nilai t hitung 2,249 dan nilai signifikan 0,038) terhadap profitabilitas. Secara simultan menunjukkan bahwa debt to equity ratio, sales, size dan curent ratio memberikan pengaruh yang simultan terhadap variabel dependen (profitbilitas) dimana F hitung sebesar 5,347 dan F tabel sebesar 2,96.
\end{abstract}

Kata Kunci: Profitabilitas, Debt to Equity Ratio (DER), Sales, Size, Curent Ratio (CR)

\section{PENDAHULUAN}

Dalam menghadapi persaingan yang kian hari kian meningkat diperlukan manajemen dengan tingkat efektifitas yang tinggi untuk mencapai tujuan 
perusahaan tersebut. Pengukuran tingkat efektifitas manajemen yang ditunjukkan oleh laba yang dihasilkan dari penjualan dan dari pendapatan investasi, dapat dilakukan dengan mengetahui seberapa besar rasio profitabilitas yang dimiliki. Dengan mengetahui rasio profitabilitas yang dimiliki perusahaan dapat memonitor perkembangan perusahaan dari waktu ke waktu (Nur Hafni Lubis, 2013: 3).

Rasio keuangan merupakan suatu perhitungan rasio dengan menggunakan laporan keuangan yang berfungsi sebagai alat ukur dalam menilai kondisi keuangan dan kinerja perusahaan. Rasio keuangan adalah angka yang diperoleh dari hasil perbandingan antara satu pos laporan keuangan dengan pos lainnya yang mempunyai hubungan yang relevan dan signifikan. Perbandingan dapat dilakukan antara satu pos dengan pos lainnya dalam satu laporan keuangan atau antarpos yang ada di antara laporan keuangan (Hery, 2016: 138).

Kemudian angka yang diperbandingkan dapat berupa angka-angka dalam satu periode maupun beberapa periode (Kasmir dalam Asri Widiastuti dan Palti Marulitua Sitorus, 2017: 2). Dalam mempelajari rasio dapat diketahui melalui pembelajaran kategori atau jenis yang berbeda dari suatu rasio, atau bisa menggunakan rasio untuk menjawab beberapa pertanyaan penting tentang operasi perusahaan. Penulis lebih memilih pendekatan yang terakhir dan memilih beberapa pertanyaan berikut sebagai petunjuk dalam penggunaan rasio keuangan (Arthur J. Keown et al, dalam Asri Widistuti, 2017: 2). Diantaranya melalui rasio leverage, sales, size, likuiditas, dan rasio profitabilitas.

Penelitian ini menggunakan ROA sebagai alat untuk mengukur profitablitas perusahaan. Rasio ini merupakan rasio yang terpenting diantara rasio rentabilitas yang ada. Return On Asset dapat merefleksikan seberapa banyak perusahaan telah memperoleh hasil atas seluruh sumberdaya keuangan yang ditanamkan pada perusahaan. Rasio ROA sering digunakan oleh top manajemen untuk mengevaluasi unit-unit usaha dalam perusahaan yang multidivisional. Manajer divisi mempunyai pengaruh yang besar terhadap aktiva yang digunakan dalam divisi tersebut, tetapi kurang mempunyai pengaruh terhadap bagaimana aktiva tersebut dibiayai karena divisi tersebut tidak merancang untuk mencari pinjaman sendiri, pengeluaran obligasi maupun saham (T. Abdu Syahri Atthar, 2012: 2).

Perusahaan yang dipilih dalam penelitian ini adalah perusahaan yang sahamnya terdaftar di Bursa Efek Indonesia (BEI) dan tergolong dalam Jakarta Islamic Index (JII) peroide yang diambil yaitu mulai dari periode 2013-2018. Perusahaan yang dipilih pada penelitian ini yaitu PT. Unilever Indonesia Tbk. Data empiris mengenai variabel-variabel yang digunakan dalam penelitian ini yaitu: debt to equityr ratio, sales, size, current ratio terhadap ROA.

Berdasarkan Pecking Order Theory yang dinyatakan oleh Weston dan Copeland dalam bukunya "Manajemen Keuangan Jilid II" bahwasanya semakin besar rasio DER, menunjukkan bahwa semakin besar biaya yang 
harus ditanggung perusahaan untuk memenuhi kewajiban yang dimilikinya sehingga dapat menurunkan profitabilitas yang dimiliki oleh perusahaan tersebut (Weston J. Fred dan Thomas E. Copeland dalam Meilinda Afriyanti, 2011: 3). Berdasarkan dari teori di atas sehingga timbul masalah dari semakin tinggi tingkat debt to equity ratio (DER), berarti komposisi hutang juga semakin tinggi, sehingga akan berakibat pada semakin rendahnya kemampuan perusahaan untuk membayarkan dividend payout ratio (DPR) kepada pemegang saham, sehingga rasio pembayaran deviden semakin rendah. DER memiliki pengaruh negatif terhadap DPR. DER yang tinggi menandakan bahwa kebutuhan ekuitas sebagian besar dipenuhi dari hutang. Seharusnya DER dari PT Unilever Indonesia Tbk rendah, nyatanya DER pada PT. Unilever Indonesia Tbk tinggi.

Menurut Hery dalam bukunya "Analisis Laporan Keuangan" apabila total aset dari suatu perusahaan tinggi maka profitabilitas dari perusahaan tersebut maka akan tinggi juga (Hery, 2016: 192). Total aset dari PT. Unilever Indonesia Tbk dari Tahun 2013 sampai Tahun 2017 mengalami kenaikkan sesuai pada grafik di bawah, seharusnya profitabilitas PT. Unilever Indonesia Tbk juga harus mengalami kenaikkan sesuai dengan total aset yang sudah diperoleh oleh PT. Unilever Undonesia Tbk. Tetapi nyatanya profi dari PT Unilever Indonesia Tbk mengalami penurunan pada Tahun 2013 sampai Tahun 2017 sesuai pada grafik di bawah. Sehingga keadaan ini berbanding terbalik dari total aset yang diperoleh oleh PT. Unilever Indonesia Tbk, data ini diperoleh dari laporan keuangan yang dipublikasikan oleh Bursa Efek Indonesia.

\section{Grafik 1. Perkembangan PT. Unilever Tbk.}
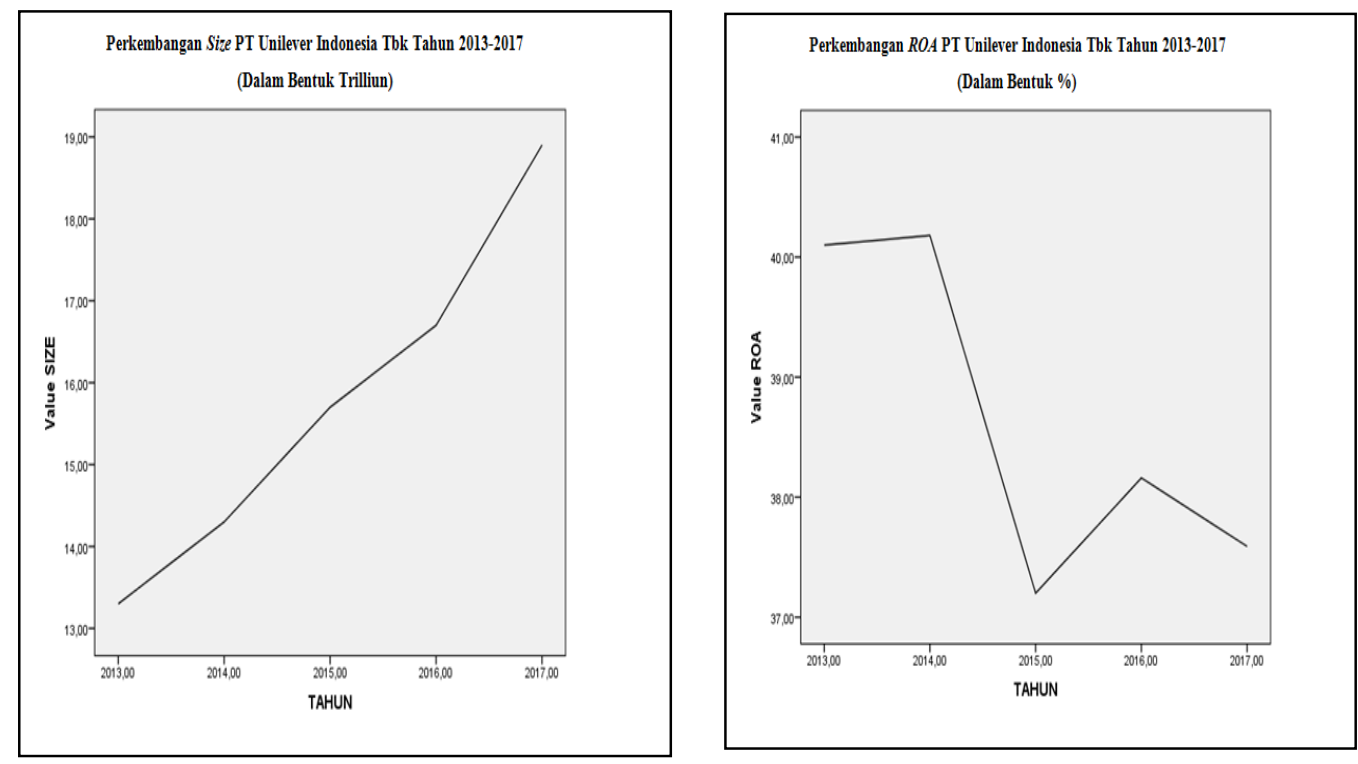

Sumber: Bursa Efek Indonesia.

Menurut I made dalam bukunya yang berjudul "Manajemen Keuangan Perusahaan" ia menjelaskan apabila jumlah S.T borrowing dan gross profit suatu perusahaan meningkat maka pendapatan dari perusahaan tersebut 
pasti akan sebanding dengan S.T borrowing dan gross profit (Made Sudan, 2011: 241). Berdasarkan teori tersebut S.T borrowing dan gross profit PT. Unilever Indonesia Tbk meningkat dari tahun ke tahun seharusnya pendapatan Unilever juga harus meningkat. Nyatanya pendapatan PT. Unilever Indonesia Tbk malah mengalami penurunan, pernyataan ini sesuai dengan grafik dibawah ini.

\section{Grafik 2. Perkembangan PT. Unilever Indonesia Tbk.}
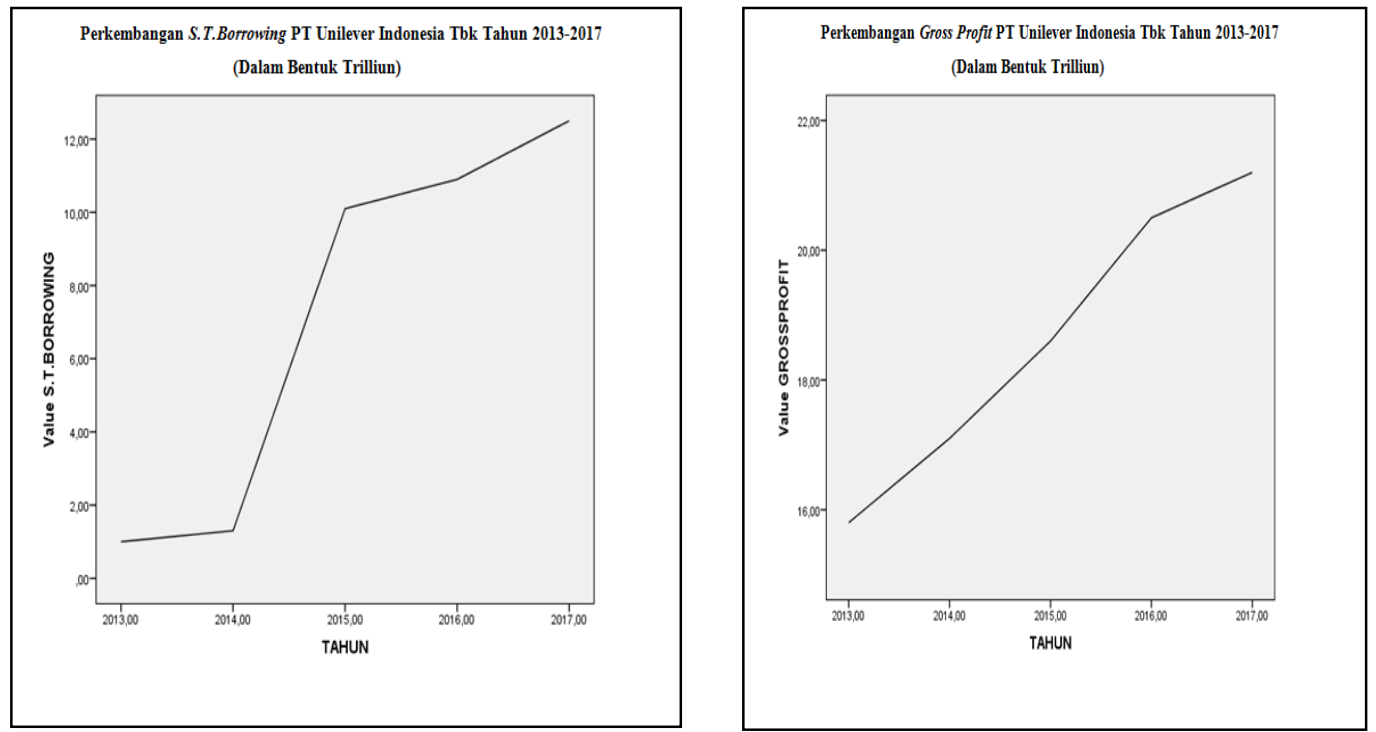

Sumber: Bursa Efek Indonesia.

Berdasarkan uraian diatas yang telah dijelaskan peneliti untuk melakukan penelitian mengenai determinan profitabilitas PT. Unilever Indonesia Tbk periode waktu yang diambil dalam penelitian ini selama 6 tahun yaitu dari tahun 2013 sampai dengan 2018. Hal ini dilakukan peneliti untuk mengetahui pengaruh profitabilitas yang dilihat melalui rasio keuangan dari tahun ke tahun yang dipublikasikan oleh perusahaan itu sendiri. Untuk itu, dalam penelitian kali ini peneliti mengambil penelitian yang berjudul: Determinan Profitabilitas PT. Unilever Indonesia Tbk.

\section{KAJIAN LITERATUR \\ Profitabilitas}

Profitabilitas adalah kemampuan perusahaan untuk menghasilkan laba pada periode tertentu. Laba sering kali menjadi salah satu ukuran kinerja perusahaan. Dimana ketika perusahaan memiliki laba yang tinggi berarti kinerjanya baik dan sebaliknya. Laba perusahaan selain merupakan indikator kemampuan perusahaan memenuhi kewajiban bagi para penyandang dananya juga merupakan elemen dalam penciptaan nilai perusahaan yang menunjukkan prospek perusahaan di masa yang akan datang (Hery, 2016: 192). 


\section{Return On Asset}

ROA merupakan rasio profitabilitas yang digunakan untuk mengukur efektivitas perusahaan dalam menghasilkan keuntungan dengan memanfaatkan total aktiva yang dimilikinya. ROA merupakan rasio antara laba sesudah pajak atau net income after tax (NIAT) terhadap total asset. Semakin besar ROA menunjukkan kinerja perusahaan semakin baik, karena return semakin besar. Secara matematis ROA dapat dirumuskan sebagai berikut (Keown et al dalam Siti Hafidoh, 26: 2011)

$R O A=\frac{N I A T}{\text { Total Asset }}$

\section{Debt to Equity Ratio (DER)}

Debt to Equity Ratio merupakan rasio yang mengukur tingkat penggunaan hutang (leverage) terhadap total modal yang dimiliki oleh masing-masing perusahaan. Secara matematis DER adalah perbandingan antara total hutang atau total debts dengan total modal. Rasio Debt to Equity Ratio dapat dirumuskan sebagai berikut (Raditya Jatismara, 30: 2010):

Debt to Equity Ratio = $\frac{\text { Total Utang }}{\text { Total Modal }}$

\section{Sales}

Penjualan memiliki pengaruh yang strategis bagi sebuah perusahaan, karena penjualan yang dilakukan harus didukung dengan harta atau aktiva dan bila penjualan ditingkatkan maka aktiva pun harus ditambah dengan mengetahui penjualan dari tahun yang sebelumnya, perusahaan dapat mengoptimalkan sumber daya yang ada (Melinda Afryanti, 2011: 28). Rumus dari penjualan yaitu sebagai barikut:

\section{Sales $=$ Ln Net sales}

\section{Size (Ukuran Perusahaan)}

Suatu perusahaan besar dan go public akan mudah untuk menuju ke pasar modal. Karena kemudahan untuk berhubungan dengan pasar modal, maka perusahaan besar memiliki fleksibilitas lebih besar untuk memperoleh dana yang sangat diperlukan untuk melaksanakan kesempatan investasi yang menguntungkan. Dengan demikian, kesempatan untuk meningkatkan profitabilitas pada perusahaan besar lebih tinggi dibandingkan dengan perusahaan kecil. Oleh karena itu ukuran perusahaan (firm size) digunakan sebagai variabel untuk menguji pengaruhnya terhadap return on assets perusahaan (Melinda Afryanti, 2011: 49). Dalam penelitian ini Size / skala perusahaan diukur dari jumlah Total Assets perusahaan dengan rumus sebagai berikut:

\section{Size $=$ Ln total assets}

\section{Curent Ratio (CR)}

Rasio lancar merupakan rasio yang digunakan untuk mengukur kemampuan perusahaan dalam memenuhi kewajiban jangka pendeknya yang segera jatuh 
tempo dengan menggunakan total aset lancar yang tersedia. Dengan kata lain, rasio lancar ini menggambarkan seberapa besar jumlah ketersediaan aset lancar yang dimiliki perusahaan dibandingkan dengan total kewajiban lancar. Oleh sebab itu, rasio lancar dihitung sebagai sebagai hasil bagi antara total aset lancar dengan total kewajiban lancar (Hery, 2016: 169), dengan rumus sebagai berikut:

\section{Kerangka Penelitian}

$$
C R=\frac{\text { Aset Lancar }}{\text { Kewajiban Lancar }}
$$

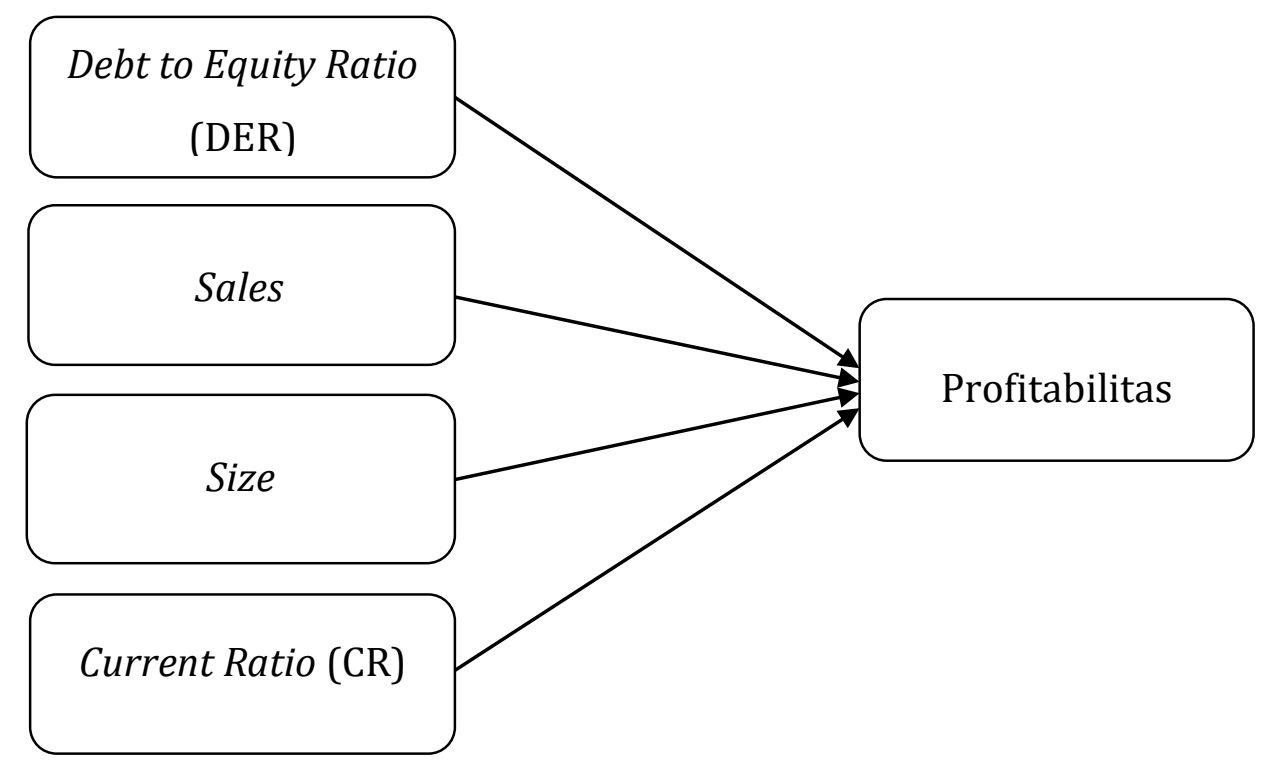

\section{Hipotesis}

Berdasarkan latar belakang permasalahan dan perumusan masalah yang dijabarkan sebelumnya, formulasi hipotesis dalam penelitian ini adalah sebagai berikut:

$\mathrm{H}_{01} \quad$ :Tidak terdapat pengaruh antara variabel debt to equity ratio terhadap profitabilitas (Return On Assets-ROA) pada PT. Unilever Indonesia Tbk.

$\mathrm{H}_{\mathrm{a} 1} \quad$ :Terdapat pengaruh signifikan antara variabel debt to equity ratio terhadap profitabilitas (Return On Assets-ROA) pada PT. Unilever Indonesia Tbk.

$\mathrm{H}_{02}$ :Tidak terdapat pengaruh antara variabel sales terhadap profitabilitas (Return On Assets-ROA) pada PT. Unilever Indonesia Tbk.

$\mathrm{H}_{2}$ :Terdapat pengaruh signifikan antara variabel sales terhadap profitabilitas (Return On Assets-ROA) pada PT. Unilever Indonesia Tbk.

$\mathrm{H}_{03}$ :Tidak terdapat pengaruh antara variabel size terhadap profitabilitas (Return On Assets-ROA) pada PT. Unilever Indonesia Tbk.

$\mathrm{H}_{\mathrm{a} 3}$ :Terdapat pengaruh signifikan antara variabel size terhadap profitabilitas (Return On Assets-ROA) pada PT. Unilever Indonesia Tbk.

$\mathrm{H}_{04}$ :Tidak terdapat pengaruh antara variabel current ratio terhadap profitabilitas (Return On Asset-ROA) pada PT. Unilever Indonesia Tbk. 
$\mathrm{H}_{\mathrm{a}}$ :Terdapat pengaruh signifikan antara variabel current ratio terhadap profitabilitas (Return On Assets-ROA) pada PT. Unilever Indonesia Tbk.

$\mathrm{H}_{05}$ :Tidak terdapat perbedaan pengaruh antara variabel debt to equity ratio, sales, size dan current ratio terhadap profitabilitas (Return On Assets-ROA)Pada PT. Unilever Indonesia Tbk.

$\mathrm{H}_{\mathrm{a} 5}$ :Terdapat perbedaan pengaruh anatara variabel debt to equity ratio, sales, size, dan current ratio terhadap profitabilitas (Return On AssetsROA) Pada PT. Unilever Indonesia Tbk.

\section{METODOLOGI PENELITIAN}

Penelitian ini menggunakan pendekatan kuantitatif yaitu data yang diukur dalam skala numerik, data dikumpulkan berdasarkan pada runtun waktu (time series) (Mudrajad Kuncoro, 2017: 23-24), yang berhubungan dengan variabel yang mempengaruhi profitabilitas yang terdiri dari debt to equity ratio, sales, size, serta curent ratio dan bersumber dari Bursa Efek Indonesia (BEI), jadi data yang digunakan dalam penelitian ini adalah data sekunder.

Lokasi penelitian adalah pada PT. Unilever Indonesia Tbk. Waktu penelitian diambil selama enam tahun. Penelitian ini dilakukan dengan menggunakan data laporan keuangan PT. Unilever Indonesia Tbk. dalam jangka tahunan yaitu pada kurun waktu enam tahun, yaitu dari Tahun 2013 sampai tahun 2018. Data perusahaan PT. Unilever Indonesia Tbk. diperoleh melalui website resmi Bursa Efek Indonesia (BEI).

Sampel penelitian adalah dari sebagian elemen/unsur yang ada dalam sebuah wilayah penelitian atau wakil dari populasi (Azuar Juliandi \& Irfan, 2013: 51). Sedangkan sampel dari penelitian ini yaitu PT. Unilever Indonesia Tbk, dan sampel yang diambil adalah bagian dari jumlah populasi laporan keuangan yang dipublikasikan selama enam tahun dari tahun 2013 sampai tahun 2018.

Metode pengumpulan data yang sesuai digunakan dalam penelitian ini adalah metode dokumentasi. Dokumentasi adalah menyelidiki rekaman-rekaman data yang telah berlalu (past). Ada 2 bentuk pengumpulan dokumentasi, yang pertama dokumentasi tertulis (printed) yaitu terdiri dari: buku, majalah, dokumen, peraturan, notulen rapat, catatan harian, jurnal, artikel, skripsi, tesis, dan laporan dan yang kedua dokumentasi elektronis (nonprinted) yaitu terdiri dari: situs internet, foto, micrifile, disket, cd, kaset, atau peralatan audio visual lainnya (Azuar Juliandi \& Irfan, 2013: 71).

Teknik analisis data dalam penelitian ini meliputi Uji asumsi klasik, terdiri dari uji normalitas, uji multikolinearitas, uji heterokedastisitas, uji autokorelasi dan uji hipotesis, uji model r2 (koefisien determinasi), uji f (uji model), uji t (uji parsial). Adapun model persamaan regresi berganda adalah sebagai berikut (Juliandi dan Irfan, 2013: 128):

$\mathrm{Y}=\mathrm{a}+\mathrm{b}_{1} \mathrm{X}_{1}+\operatorname{Ln} \mathrm{b}_{2} \mathrm{X}_{2}+\operatorname{Ln} \mathrm{b}_{3} \mathrm{X}_{3}+\mathrm{b}_{4} \mathrm{X}_{4}+\mathrm{e}$

Keterangan :

$\mathrm{Y}=$ Profitabilitas 


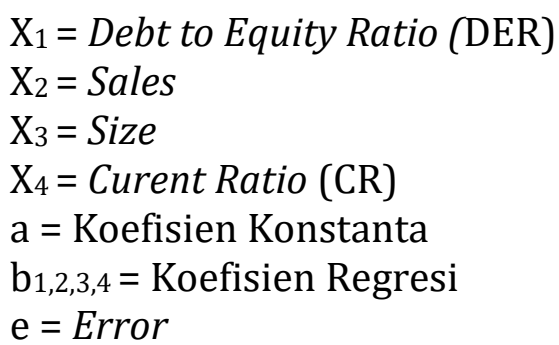

\section{HASIL DAN PEMBAHASAN}

\section{Gambaran Umum Perusahaan PT Unilever Indonesia,Tbk}

PT Unilever Indonesia Tbk ("Perseroan") didirikan pada tanggal 5 Desember 1933 dengan nama Lever's Zeepfabrieken N.V. dengan akta No. 23 oleh Tn. A.H. van Ophuijsen, notaris di Batavia, disetujui oleh Gouverneur Generaal van Nederlandsch-Indie dengan surat No. 14 tanggal 16 Desember 1933, didaftarkan di Raad van Justitie di Batavia dengan No. 302 pada tanggal 22 Desember 1933, dan diumumkan dalam Javasche Courant tanggal 9 Januari 1934, Tambahan No. 3 (www.idx.co.id).

Nama Perseroan diubah menjadi "PT Unilever Indonesia" dengan akta No. 171 tanggal 22 Juli 1980 dari notaris Ny. Kartini Muljadi, S.H.. Selanjutnya perubahan nama Perseroan menjadi "PT Unilever Indonesia Tbk", dilakukan dengan akta notaris Tn. Mudofir Hadi, S.H., No. 92 tanggal 30 Juni 1997. Akta ini disetujui oleh Menteri Kehakiman dalam Surat Keputusan No. C21.049HT.01.04-TH.1998 tanggal 23 Februari 1998 dan diumumkan dalam Berita Negara No. 39 tanggal 15 Mei 1998, Tambahan No. 2620. Anggaran Dasar Perseroan telah mengalami beberapa kali perubahan, terakhir dengan akta notaris No. 22 tanggal 20 Juni 2016 dari Haji Syarif Siangan Tanudjaja, S.H., notaris di Jakarta, terkait dengan perubahan tempat kedudukan Perseroan. Akta ini telah memperoleh persetujuan dari Menteri Hukum dan Hak Asasi Manusia Republik Indonesia dalam Surat Keputusan No. AHU0011673.AH.01.02.Tahun 2016 tanggal 21 Juni 2016 (www.idx.co.id).

Kegiatan usaha Perseroan meliputi bidang produksi, pemasaran dan distribusi barang-barang konsumsi yang meliputi sabun, deterjen, margarin, makanan berinti susu, es krim, produk-produk kosmetik, minuman dengan bahan pokok teh dan minuman sari buah. Berdasarkan Rapat Umum Pemegang Saham Tahunan tanggal 13 Juni 2000, yang diaktakan dengan akta No. 82 tanggal 14 Juni 2000 dari notaris Singgih Susilo, S.H. Perseroan juga bertindak sebagai distributor utama untuk produk-produk Perseroan dan penyedia jasa penelitian pemasaran. Akta ini telah disetujui oleh Menteri Hukum dan Perundang-undangan (Menteri Kehakiman) Republik Indonesia dalam Surat Keputusan No. C-18482 HT.01.04-TH.2000. Perseroan mulai beroperasi secara komersial tahun 1933 (www.idx.co.id). 
Deskripsi Data Penelitian

Tabel 1

Data Triwulan dari Tahun 2013-2018

\begin{tabular}{|c|c|c|c|c|c|c|}
\hline \multirow[t]{2}{*}{ Tahun } & \multirow[t]{2}{*}{ Triwulan } & $R O A$ & DER & Sales & Size & Curent Ratio \\
\hline & & $\mathbf{Y}$ & $\mathrm{X1}$ & $\mathrm{X} 2$ & X3 & $X 4$ \\
\hline \multirow{4}{*}{2013} & I MAR & 44,38 & 1,39 & 12,879 & 13,111 & 83,99538866 \\
\hline & II JUN & 39,79 & 2,34 & 13,188 & 13,152 & 75,84922647 \\
\hline & III SEP & 40,88 & 1,42 & 13,362 & 13,125 & 85,3641514 \\
\hline & IV DES & 40,10 & 2,14 & 13,488 & 13,125 & 69,63571933 \\
\hline \multirow{4}{*}{2014} & I MAR & 38,03 & 1,55 & 12,941 & 13,156 & 87,21272814 \\
\hline & II JUN & 35,70 & 2,74 & 13,245 & 13,203 & 77,87424897 \\
\hline & II SEP & 35,59 & 1,77 & 13,416 & 13,181 & 84,57245427 \\
\hline & IV DES & 40,18 & 2,11 & 13,538 & 13,155 & 71,49139204 \\
\hline \multirow{4}{*}{2015} & I MAR & 43,10 & 1,33 & 12,974 & 13,169 & 87,28517025 \\
\hline & II JUN & 35,55 & 2,66 & 13,274 & 13,217 & 73,09312897 \\
\hline & III SEP & 34,89 & 1,78 & 13,440 & 13,204 & 78,96632075 \\
\hline & IV DES & 37,20 & 2,26 & 13,562 & 13,196 & 65,39705291 \\
\hline \multirow{3}{*}{2016} & I MAR & 37,71 & 1,60 & 12,999 & 13,222 & 77,94149997 \\
\hline & II JUN & 34,86 & 2,87 & 13,317 & 13,277 & 71,69272882 \\
\hline & IV DES & 38,16 & 2,56 & 13,473 & 13,224 & 60,56 \\
\hline \multirow{4}{*}{2017} & I MAR & 42,20 & 1,79 & 13,035 & 13,269 & 74,96996853 \\
\hline & II JUN & 37,58 & 2,93 & 13,328 & 13,258 & 65,46083915 \\
\hline & III SEP & 37,06 & 1,93 & 13,494 & 13,275 & 71,81836569 \\
\hline & IV DES & 37,05 & 2,65 & 13,615 & 13,277 & 63,36931342 \\
\hline \multirow{3}{*}{2018} & I MAR & 36,34 & 1,89 & 13,031 & 13,306 & 53,09119791 \\
\hline & II JUN & 34,39 & 3,10 & 13,326 & 13,312 & 103,2037659 \\
\hline & III SEP & 48,69 & 1,23 & 13,499 & 13,301 & 157,67219 \\
\hline
\end{tabular}

Dari tabel di atas dampak bahwa semua variabel mengalami fluktuatif naik turun setiap tahunnya. Pada variabel return on assets (ROA) persentasi tertinggi terjadi pada tahun 2018 triwulan ketiga yaitu 48,69, sedangkan persentasi terendah terjadi pada tahun 2018 triwulan kedua yaitu 34,39. Pada variabel debt to equity ratio (DER) persentasi tertinggi terjadi pada tahun 2018 triwulan kedua, sedangkan persentasi terendah terjadi pada tahun 2018 triwulan ketiga. Pada variabel sales persentasi tertinggi terjadi pada tahun 2017 triwulan keempat yaitu 13,615, sedangkan persentasi terendah terjadi pada tahun 2013 triwulan pertama yaitu 12,879. Pada variabel size persentasi tertinggi terjadi pada tahun 2018 triwulan kedua yaitu 13,312, sedangkan persentasi terendah terjadi pada tahun 2013 
triwulan pertama 13,111. Terakhir pada variabel current ratio (CR) persentasi tertinggi terjadi pada tahun 2018 triwulan ketiga yaitu 157,67219, sedangkan persentasi tertinggi terjadi pada tahun 2018 triwulan pertama yaitu 53,09119791.

\section{Analisi Data Penelitian}

\section{Uji Asumsi Klasik}

\section{Uji Normalitas}

Pengujian normalitas data dilakukan untuk melihat apakah dalam model regresi, variabel dependen dan independenya memiliki distribusi normal atau tidak. Jika data menyebar di sekitar garis diagonal dan mengikuti arah diagonal maka model regresi memenuhi asumsi normalitas (Juliandi dan Irfan, 2013: 169). Normalitas ini dapat dilihat dengan menggunakan normal probability plot. Hasil dari normalitas adalah sebagai berikut:

\section{Gambar 1}

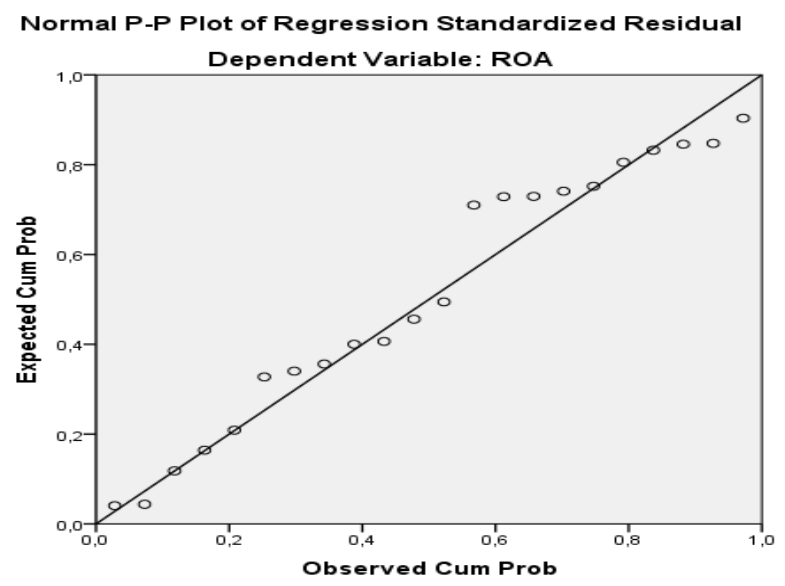

Sumber: Data Sekunder diolah, 2018

Dari tampilan grafik normal P-P Plot Regression tersebut bentuk penyebaran data berada pada sekitaran garis diagonal dan mengikuti arah garis diagonal. Maka dapat disimpulkan bahwa asumsi normalitas dapat terpenuhi, artinya semua variabel dalam penelitian ini terdistribusi normal.

\section{Uji Multikolinearitas}

Uji multikolinearitas dilakukan untuk menguji apakah dalam sebuah model regresi terdapat korelasi yang kuat antara variabel independen yang digunakan dalam penelitian. Model regresi linier yang baik adalah yang tidak terjadi korelasi antara variabel independennya (non-multikolinearitas) (Juliandi dan Irfan, 2013: 169). Multikolinearitas dapat dilihat dari nilai Variance Inflation Factor atau VIF. Nilai cut-off yang umum dipakai adalah nilai VIF kurang dari 10 (Erna Novasari, 2013: 44). Hasil uji multikoliniearitas adalah sebagai berikut: 


\section{Gambar 2}

\section{Coefficients $^{\mathrm{a}}$}

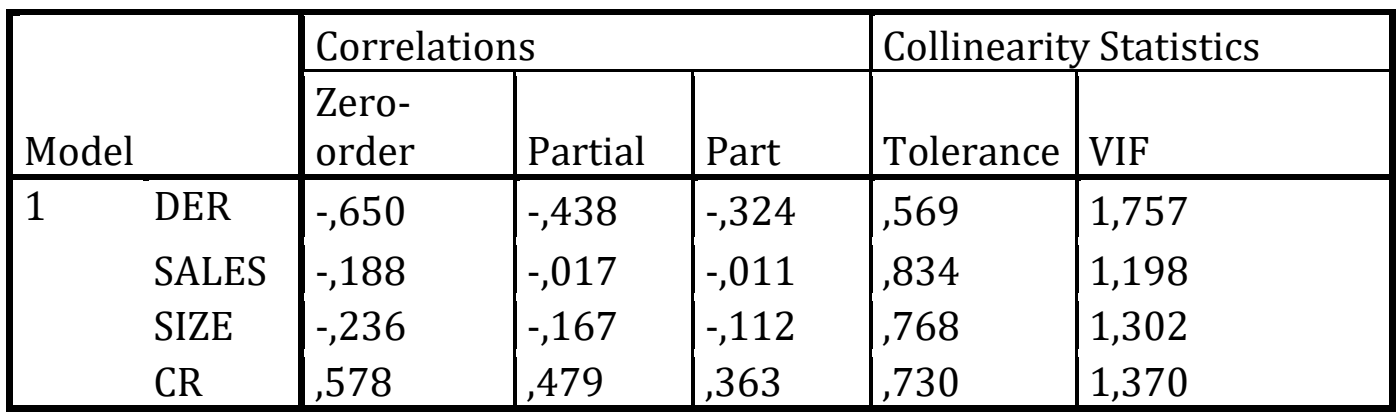

a. Dependent Variable: ROA

Sumber: Data Sekunder diolah, 2018

Terlihat nilai VIF dari gambar di atas bahwa Variance Inflation Factor (VIF) semua variabel lebih kecil dari 10. Maka dapat disimpulkan bahwa tidak terjadi multikolinearitas pada model regresi.

\section{Uji Heteroskedastisitas}

Uji heteroskedastisitas digunakan untuk menguji apakah dalam model regresi terjadi ketidaksamaan varians dari residual dari suatu pengamatan yang lain. Jika variasi residual dari saru pengamatan ke pengamatan lain tetap, maka disebut homokedastisitas dan jika varians berbeda disebut heteroskedastisitas. Model yang baik adalah model yang tidak terjadi heteroskedastisitas. Dasar pengambilan keputusannya adalah jika pola tertentu, seperti titik-titik (poin-poin) yang ada membentuk suatu pola tertentu yang teratur, maka terjadi heteroskedastisitas. Jika tidak ada pola yang jelas, serta titik-titik (poin-poin) menyebar dibawah dan diatas angka 0 pada sumbu Y, maka tidak terjadi terjadi heteroskedastisitas (Juliandi dan Irfan, 2013: 171). Hasil uji heteroskedastisitas adalah sebagai berikut:

\section{Gambar 3}

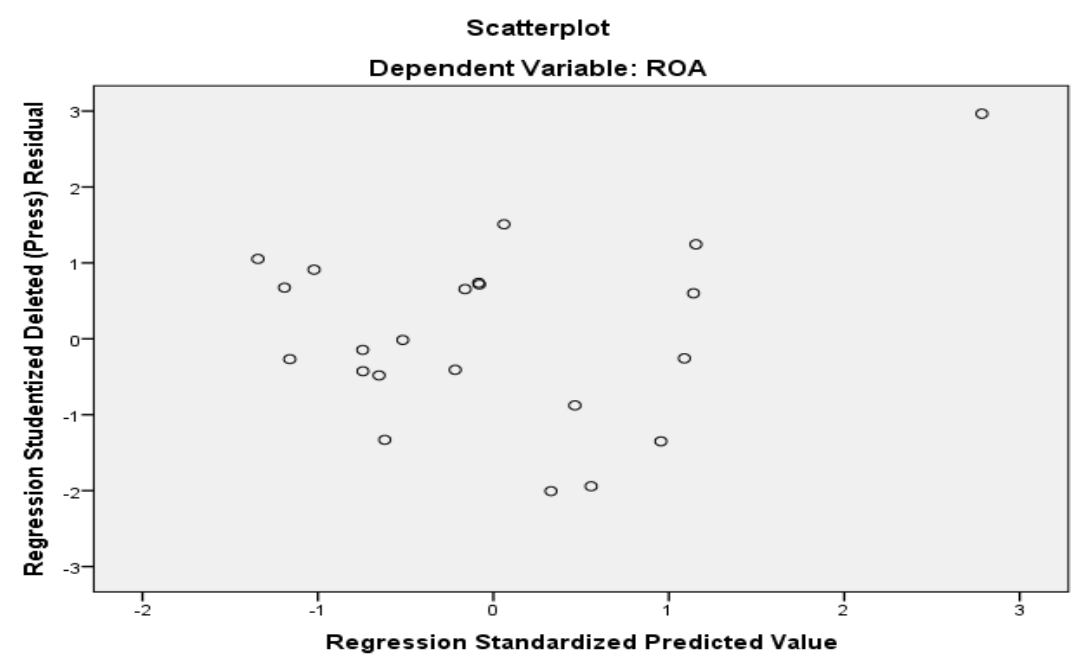

Sumber: Data Sekunder diolah, 2018 
Dari hasil uji heteroskedastisitas diatas, dimana hasil yang menggambarkan sebaran titik-titik yang menyebar secara acak dan tidak membentuk pola tertentu. Selain itu titik-titik data menyebar dibawah dan di atas angka 0 pada sumbu Y. Maka dengan hasil pengamatan tersebut dapat disimpulkan bahwa regresi linier pada penelitian ini tidak terjadi gejala heteroskedastisitas.

\section{Uji Autokorelasi}

Uji autokorelasi bertujuan untuk menguji apakah dalam sebuah model regresi linear ada korelasi antara kesalahan pengganggu dalam periode ke $t$ dengan kesalahan pada periode ke-t (sebelumnya). Jika terjadi korelasi, maka dinamakan dalam problem autokorelasi. Model regresi yang baik adalah model yang bebas dari autokorelasi. Salah satu cara mengidentifikasinya adalah dengan melihat nilai Durbin Watson (D-W) (Juliandi dan Irfan, 2013: 173):

1. Jika nilai D-W dibawah -2 berarti ada autokorelasi positif.

2. Jika nilai $\mathrm{D}-\mathrm{W}$ diantara -2 sampai +2 berarti tidak ada autokorelasi.

3. Jika nilai $\mathrm{D}-\mathrm{W}$ diatas +2 berarti ada autokorelasi negatif.

\section{Gambar 4}

Model Summary

\begin{tabular}{|c|c|c|c|c|c|c|c|c|c|c|}
\hline \multirow[b]{2}{*}{ Model } & \multirow[b]{2}{*}{$\mathrm{R}$} & \multirow[b]{2}{*}{ R Square } & \multirow[b]{2}{*}{$\begin{array}{l}\text { Adjusted R } \\
\text { Square }\end{array}$} & \multirow[b]{2}{*}{$\begin{array}{l}\text { Std. Error of } \\
\text { the Estimate }\end{array}$} & \multicolumn{5}{|c|}{ Change Statistics } & \multirow[b]{2}{*}{$\begin{array}{l}\text { Durbin- } \\
\text { Watson }\end{array}$} \\
\hline & & & & & $\begin{array}{c}\text { R Square } \\
\text { Change }\end{array}$ & F Change & df1 & $d f 2$ & $\begin{array}{c}\text { Sig. F } \\
\text { Change }\end{array}$ & \\
\hline 1 & $.746^{\mathrm{a}}$ & .557 & 453 & 2,63342 & 557 & 5,347 & 4 & 17 & .006 & 1,710 \\
\hline
\end{tabular}

a. Predictors: (Constant), CR, SALES, SIZE, DER

b. DependentVariable: ROA

Sumber: Data Sekunder diolah, 2018

Dari hasil analisis data menggunakan SPSS di atas menunjukan nilai Durbin Watson sebesar 1,710, maka dapat disimpulkan bahwa nilai D-W berada diantara -2 sampai +2 dengan demikian regresi dalam penelitian ini tidak ada autokorelasi. Sehingga asumsi klasik dari penelitian ini terpenuhi.

\section{Model Persamaan Regresi}

Analisis yang digunakan dalam penelitian ini menggunakan analisis regresi linier berganda. Regresi adalah alat análisis yang digunakan untuk mengukur seberapa jauh pengaruh variabel independen terhadap variabel dependen. Adapun variabel yang akan diteliti adalah DER (X1), Sales (X2), Size (X3), CR(X4) dan ROA (Y) sebagai variabel dependennya. 


\section{Gambar 5}

\begin{tabular}{|c|c|c|c|c|c|c|c|c|}
\hline \multicolumn{9}{|c|}{ Coefficients $^{a}$} \\
\hline \multirow{2}{*}{\multicolumn{2}{|c|}{ Model }} & \multicolumn{2}{|c|}{ Unstandardized Coefficients } & \multirow{2}{*}{$\begin{array}{c}\begin{array}{c}\text { Standardized } \\
\text { Coefficients }\end{array} \\
\text { Beta }\end{array}$} & \multirow[b]{2}{*}{$t$} & \multirow[b]{2}{*}{ Sig. } & \multicolumn{2}{|c|}{$95,0 \%$ Confidence Interval for B } \\
\hline & & $B$ & Std. Error & & & & Lower Bound & Upper Bound \\
\hline \multirow[t]{5}{*}{1} & (Constant) & 136,824 & 140,626 & & 973 & 344 & $-159,871$ & 433,518 \\
\hline & DER & $-2,677$ & 1,333 &,- 429 & $-2,008$ &, 061 & $-5,490$ & , 136 \\
\hline & SALES &,- 195 & 2,792 &,- 012 &,- 070 &, 945 & $-6,086$ & 5,695 \\
\hline & SIZE & $-7,251$ & 10,414 &,- 128 &,- 696 & ,496 & $-29,223$ & 14,721 \\
\hline & $\mathrm{CR}$ & 073 & 033 & 425 & 2,249 & 038 &, 005 & 142 \\
\hline
\end{tabular}

Sumber: Data Sekunder diolah, 2018

Berdasarkan hasil regresi linear berganda diatas didapatkan model persamaan regresi sebagai berikut:

\section{$Y=136,824-2,677$ X1 -0,195 X2 - 7,251 X3+0,073 X4}

Tanda positif menunjukkan adanya hubungan yang cenderung mengalami peningkatan, sedangkan tanda negatif menunjukkan adanya hubungan yang mengalami kecenderungan menurun terhadap variabel independennya. Berdasarkan persamaan regresi di atas maka dapat dijelaskan:

1. Dalam persamaan koefisien regresi di atas, konstanta $(\alpha)$ adalah sebesar $136,824 \%$ hal ini berarti jika tidak ada perubahan variabel DER, sales, size, CR tetap sebesar $136,824 \%$.

2. Nilai koefisien DER yaitu sebesar $-2,677 \%$. Artinya jika variabel DER mengalami peningkatan sebesar $1 \%$ maka profitabilitas akan turun sebesar 2,677\% dengan asumsi variabel lain konstan

3. Nilai koefisien sales yaitu sebesar $-0,195 \%$. Artinya jika variabel sales mengalami peningkatan sebesar $1 \%$ maka profitabilitas akan turun sebesar 0,195\% dengan asumsi variabel lain konstan.

4. Nilai koefisien size yaitu sebesar $-7,251 \%$. Artinya jika variabel sales mengalami peningkatan sebesar $1 \%$ maka profitabilitas akan turun sebesar 7,251\% dengan asumsi variabel lain konstan.

5. Nilai koefisien CR yaitu sebesar 0,073\%. Artinya jika variabel CR mengalami peningkatan sebesar $1 \%$ maka profitabilitas akan meningkat sebesar 0,073\% dengan asumsi variabel lain konstan.

\section{Uji t (Hipotesis)}

Uji t bertujuan utuk menguji pengaruh masing-masing variabel independen (pengetahuan, motivasi, persepsi risiko dan modal investasi minimal) terhadap variabel dependen (minat berinvestasi di Pasar Modal). Kriteria penarikan kesimpulan alternatif I (dengan membandingkan nilai statistik yang dihitung dengan yang ditabelnya), tolak $\mathrm{HO}$ jika nilai statistik yang dihitung lebih besar dari nilai statistik tabelnya dan terima HO jika nilai statistik yang dihitung lebih kecil dari nilai statistik tabelnya.

Kriteria penarikan kesimpulan alternatif II (dengan membandingkan nilai probabilitas yang dihitung dengan nilai probabilitas yang ditetapkan), tolak H0 jika nilai probabilitas kesalahan yang dihitung lebih kecil dari probabilitas kesalahan yang ditetapkan (Sig, $\alpha$ 0.05), terima H0 jika probabilitas 
kesalahan yang dihitung lebih besar dari probabilitas kesalahan yang ditetapkan (Sig > $\alpha 0.05$ ) (Azuar Juliandi dan Irfan, 2013: 97):

Hasil analisis regresi secara parsial adalah sebagai berikut:

\section{Gambar 6}

Coefficients $^{a}$

\begin{tabular}{|c|c|c|c|c|c|c|}
\hline \multirow{2}{*}{\multicolumn{2}{|c|}{ Model }} & \multicolumn{2}{|c|}{ Unstandardized Coefficients } & \multirow{2}{*}{$\begin{array}{c}\text { Standardized } \\
\text { Coefficients } \\
\text { Beta }\end{array}$} & \multirow[b]{2}{*}{$\mathrm{t}$} & \multirow[b]{2}{*}{ Sig. } \\
\hline & & $\mathrm{B}$ & Std. Error & & & \\
\hline \multirow[t]{5}{*}{1} & (Constant) & 136,824 & 140,626 & & .973 & .344 \\
\hline & DER & $-2,677$ & 1,333 &,- 429 & $-2,008$ & .061 \\
\hline & SALES &,- 195 & 2,792 &,- 012 &,- 070 & .945 \\
\hline & SIZE & $-7,251$ & 10,414 &,- 128 &,- 696 & 496 \\
\hline & CR & .073 & 033 & 425 & 2,249 & 038 \\
\hline
\end{tabular}

a. Dependent Variable: ROA

Sumber: Data Sekunder diolah, 2018

1. Nilai probabilitas DER, yakni 0,061, lebih besar dari tingkat signifikansi, yaitu 0,05 , maka disimpulkan bahwa pengaruh yang terjadi antara DER dengan variabel profitabilitas PT. Unilever Indonesia Tbk adalah tidak signifikan secara statistik. Sedangkan nilai thitung $<$ tabel, yakni $(-2,008<$ 2,086) sehingga DER berpengaruh negatif terhadap profitabilitas. Hal ini berarti pengaruh antara DER terhadap profitabilitas tidak signifikan yaitu Ho diterima dan Ha ditolak.

2. Nilai probabilitas sales, yakni 0,945, lebih besar dari tingkat signifikansi, yaitu 0,05 , maka disimpulkan bahwa pengaruh yang terjadi antara sales dengan variabel profitabilitas PT. Unilever Indonesia Tbk tidak signifikan secara statistik. Sedangkan nilai thitung $<t_{\text {tabel, }}$ yakni $(-0,070<2,086)$. Hal ini berarti pengaruh antara sales terhadap profitabilitas tidak signifikan yaitu Ho diterima dan Ha ditolak..

3. Nilai probabilitas size, yakni 0,496, lebih besar dari tingkat signifikansi, yaitu 0,05 , maka disimpulkan bahwa pengaruh yang terjadi antara size dengan variabel profitabilitas PT. Unilever Indonesia Tbk tidak signifikan secara statistik. Sedangkan nilai thitung $<$ tabel, yakni $(-0,696<2,086)$. Hal ini berarti pengaruh antara size terhadap profitabilitas tidak signifikan yaitu Ho diterima dan Ha ditolak.

4. Nilai probabilitas CR, yakni 0,038, lebih kecil dari tingkat signifikansi, yakni 0,05 , maka disimpulkan bahwa pengaruh yang terjadi antara CR dengan variabel profitabilitas PT. Unilever Indonesia Tbk adalah signifikan secara statistik. Sedangkan nilai thitung $<$ ttabel, yakni $(2,249>2,086)$ sehingga DER berpengaruh positif terhadap profitabilitas. Hal ini berarti pengaruh antara CR terhadap profitabilitas signifikan yaitu Ho ditolak dan Ha diterima. 


\section{Uji F (Simultan)}

\section{Gambar 7}

ANOVA $^{\text {a }}$

\begin{tabular}{|ll|r|r|r|r|r|}
\hline \multicolumn{2}{|c|}{} & \multicolumn{1}{c|}{$\begin{array}{c}\text { Sum of } \\
\text { Squares }\end{array}$} & df & Mean Square & F & Sig. \\
\hline 1 & Regression & 148,333 & 4 & 37,083 & 5,347 &, $006^{\text {b }}$ \\
& Residual & 117,893 & 17 & 6,935 & & \\
& Total & 266,226 & 21 & & & \\
\hline
\end{tabular}

a. Dependent Variable: ROA

b. Predictors: (Constant), CR, SALES, SIZE, DER

Sumber: Data Sekunder diolah, 2018

Hasil pengolahan data terlihat bahwa variabel independen (DER, Sales, Size, CR) mempunyai nilai probabilitas atau signifikansi sebesar 0,006 lebih kecil dari tingkat signifikansi yakni 0,05 (Sig. 0,006<0,05), dan $F_{\text {hitung }}>$ $F_{\text {tabel }}(5,347>2,96)$. Dengan demikian berdasarkan hasil analisis di atas maka data dalam penelitian ini adalah signifikan dan variabel independent (DER, Sales, Size, CR) memberikan pengaruh simultan terhapan variabel dependen (profitabilitas)

\section{Koefisien Determinasi ( $\left.\mathbf{R}^{2}\right)$}

Nilai R-Sqare adalah nilai untuk melihat bagaimana variasi nilai variabel terikat dipengaruhi oleh variasi nilai variabel bebas (Azuar Juliandi dan Irfan, 2013: 97):

\section{Gambar 8}

Model Summary

\begin{tabular}{|l|l|r|r|r|}
\hline Model & $\mathrm{R}$ & $\mathrm{R}$ Square & $\begin{array}{c}\text { Adjusted } \mathrm{R} \\
\text { Square }\end{array}$ & $\begin{array}{c}\text { Std. Error of } \\
\text { the Estimate }\end{array}$ \\
\hline 1 & $.746^{\mathrm{a}}$ & .557 & .453 & 2,63342 \\
\hline
\end{tabular}

a. Predictors: (Constant), CR, SALES, SIZE, DER

b. Dependent Variable: ROA

Sumber: Data Sekunder diolah, 2018

Besarnya koefisien determinasi dari hasil pengujian dapat dilihat pada tabel Adjusted $R$ Square pada model summary di atas, dari hasil pengujian tersebut didapatkan Adjusted $R$ Square sebesar 0,453. Hal ini menunjukkan bahwa $45,3 \%$ variasi profitabilitas dapat dijelaskan oleh keempat variabel independen yang digunakan pada penelitian (DER, sales, size, CR). Sisanya $(100 \%-45,3 \%=54,7 \%)$ dijelaskan oleh variabel lain yang mempengaruhi profitabilitas yang tidak digunakan dalam penelitian.

\section{SIMPULAN}

1. Secara parsial variabel DER berpengaruh negatif dan tidak signifikan (dengan nilai $t$ hitung -2,008 dan nilai signifikan 0,061) terhadap profitabilitas PT. Unilever Indonesia Tbk tahun 2013-2018. 
2. Secara persial variabel Sales berpengaruh negatif dan tidak signifikan (dengan nilai $t$ hitung $-0,070$ dan nilai signifikan 0,945 ) terhadap profitabilitas PT. Unilever Indonesia Tbk tahun 2013-2018.

3. Secara parsial variabel Size berpengaruh negatif dan tidak signifikan (dengan nilai $t$ hitung -0,696 dan nilai signifikan 0,496) terhadap profitabilitas PT. Unilever Indonesia Tbk tahun 2013-2018.

4. Secara parsial variabel CR berpengaruh positif dan signifikan (dengan nilai t hitung 2,249 dan nilai signifikan 0,038) terhadap profitabilitas PT. Unilever Indonesia Tbk tahun 2013-2018.

5. Berdasarkan uji Determinasi menunjukkan bahwa nilai R-Square sebesar 45,3\% yang dipengaruhi oleh DER, Sales, Size, dan CR sedangkan $54,7 \%$ dipengaruhi oleh variabel lain yang tidak termasuk dalam model regresi.

\section{DAFTAR PUSTAKA}

Afriyanti, Meilinda. (2011). Analisis Pengaruh Curent Ratio, Total Asset Turnover, Debt To Equity Ratio, dan Size ROA (return on asset) (Studi pada Perusahaan Manufaktur yang Terdaftar di BEI pada tahun 20062009. (Skripsi Fakultas Ekonomi Universitas Diponegoro, Semarang)

Ema Novasari. (2013). Pengaruh PER, ROA dan DER Terhadap Harga Saham Perusahaan Sub-Sektor Industri Textile yang Go Publik di BEI Tahun 2009-2011" (Skripsi, Fakultas Ekonomi Universitas Negeri Semarang)

Hafidoh, Siti. (2017). Analisis Faktor-Faktor Yang Mempengaruhi Keputusan Hedging pada Perusahaan Manufaktur yang Terdaftar di Bursa Efek Indonesia Tahun 2013-2015, (Skripsi, Fakultas Ekonomi dan Bisnis Lampung, Bandar Lampung)

Hery. (2016). Analisis Laporan Keuangan Integreted and Komprehensif Edition. Jakarta: Grasindo.

https://www.idx.co.id/perusahaan-tercatat/profil-perusahaantercatat/detail-profile-perusahaan-tercatat/?kodeEmiten=UNVR

Jatismara, Raditya. (2011). Analisis Pengaruh TATO, DER, Dividend, Sales, dan Curent Ratio, Terhadap Return On Asset.(Studi pada Perusahaan Manufaktur yang Listed di Bursa Efek Indonesia Periode Tahun 2008-2010). (Skripsi, Fakultas Ekonomi, Universitas Diponegoro, Semarang)

Juliandi, Azuar dan Irfan. (2009). Metodologi Penelitian Kuantitatif Untuk Ilmu-Ilmu Bisnis. Bandung Citapustaka Media Perintis, 2013.

Kuncoro, Mudrajad. (2009). Metode Riset Untuk Bisnis dan Ekonomi. Jakarta: PT Gelora Aksara Pratama.

Widiastuti , Asri dan Palti Marulitua Sitorus. (2017). Analisis Laporan Kinerja Keuangan pada Perusahaan Telekomunikasi PT. Telekomunikasi Indonesia Periode 2011-2015 Pendekatan Rasio Keuangan dengan Rata-Rata Industri. eProceedings of Management, 202. 